\title{
Does English Help You Accomplish More? Exploring the Instrumentality of English Learning in East and Southeast Asia
}

\author{
Huiyu Zhang ${ }^{1}$ \\ ${ }^{1}$ School of International Studies, Zhejiang University, Hangzhou, China \\ Correspondence: Huiyu Zhang, School of International Studies, Zhejiang University, Hangzhou, China. E-mail: \\ zhanghuiyu@zju.edu.cn
}

Received: March 20, 2019 Accepted: April 18, 2019 Online Published: May 8, 2019

doi:10.5539/ijel.v9n3p279 URL: https://doi.org/10.5539/ijel.v9n3p279

\begin{abstract}
This study empirically investigates the relationship between English proficiency and personal accomplishment in East and Southeast Asia. With the database of AsiaBarometer Survey 2006 and 2007, 15082 questionnaire respondents from China, Hong Kong of China, Japan, Korea, Singapore, Taiwan of China, Vietnam, Cambodia, Indonesia, Laos, Malaysia, Myanmar, the Philippines and Thailand formed the sample. We present the following findings with correlation and regression analysis: a) English proficiency positively influences personal accomplishment; b) the focal relationship is partly mediated by income, career and quality of life; and c) the focal relationship is positively moderated by international involvement. Such findings disclose and confirm the instrumentality of English learning in globalization. Theoretical and practical implications of the results are discussed.
\end{abstract}

Keywords: globalization, English proficiency, accomplishment, east and southeast Asia

\section{Introduction}

Globalization, as one of the most important socio-economic characteristics in the modern world, has dramatically altered people's life by involving them in all kinds of international activities (Vandenbroucke, 2016). With the opportunities to study, travel or work in foreign countries and areas, and other forms of international exposure, people, especially whose mother tongues are not prevailing in the world, have gradually and commonly recognized the importance of acquiring English as a global language (Smotrova, 2009; Kubota \& McKay, 2009). The learning of English as a Foreign/Second Language (EFL/ESL) has become a nationwide endeavor in many countries (Smotrova, 2009; Bolton, 2008; Crystal, 2012; Bolton \& Graddol, 2012; Melitz, 2016; Vandenbroucke, 2016), and English has been made a compulsory course in middle schools and universities (Wu, 2001; Wolff, 2010; Bolton \& Botha, 2015a, 2015b) and an important medium of instruction in school curriculum (Kang, 2012; Botha, 2013; Kamwangamalu, 2013; Wei \& Su, 2015; Bolton \& Botha, 2015b; He \& Chiang, 2016). At the individual level, many people take learning English as their primary strategy in individual language management and planning and believe that English proficiency will benefit them in one way or another. At the national level, considering the crucial role of English in sustaining international exchanges of labor, knowledge, capital and commodities (Kubota \& McKay, 2009), many countries and areas encourage or even force individuals to learn English by presenting related foreign language education policies (Nunan, 2003; Hu, 2008; Kirkpatrick, 2014; Jones, 2016). The increasing English learning fever drives us to explore, exploit and examine some essential questions: Why do people learn English? Do people really benefit from learning English? If so, how?

To explain the popularity and motivations of English learning, extant literature has explored and stressed the importance of English proficiency by analyzing the benefits and advantages embodied in the language skill (e.g., Vaillancourt, 1996; Davila \& Mora, 2000; Dustmann \& Fabbri, 2003; Chiswick, 2008). Economic analysis out-stands among various perspectives, such as historical (Kaiwar \& Mazumdar, 2003), social (Gardner, 2002), political (Newton, 2015) and cultural (Schiffman, 1998) considerations, by estimating and examining the economic returns to the human capital of English competence. Such studies not only present theoretical arguments and qualitative cases, as studies from traditional perspectives usually do, but also offers quantitative evidences that convincingly prove and generalize related findings (Vaillancourt, 1996; Breton, 1998; Bloom \& Grenier, 1996; Davila \& Mora, 2000; Chiswick \& Miller, 1995, 2003, 2010, 2015; Chiswick, 2008). 
The literature of language economics has presented fruitful empirical findings and greatly enriched our understanding of the relationship between English proficiency and economic factors. However, some gaps have emerged. As to the addressed topics, most of the previous studies have focused on the relationship between English proficiency and income, especially the role of English skills in the economic assimilation of immigrants in English-speaking countries (Carliner, 2000; Chiswick \& Miller, 2003; Dustmann \& Fabbri, 2003; Van Tubergen \& Kalmijn, 2005, 2009), the economic returns to learning English in domestic labor market is largely neglected with only a few exceptions (Angrist \& Lavy, 1997; Angrist, Chin, \& Godoy, 2008; Azam et al., 2013; Stöhr, 2015). Moreover, while English, as a global language, has deeply penetrated into and exerted influence on people's internationalization and personal lives (Botha, 2014), the influence of English proficiency on other important socio-economic factors, such as success, happiness, and accomplishment, is not adequately discussed with little empirical work. As to the research contexts of empirical efforts, most of the previous studies are set in the background of the vast immigration in developed economies, such as Canada (Vaillancourt, 1996; Breton, 1998), United States (Bloom \& Grenier, 1996; Davila \& Mora, 2000), UK (Dustmann \& Fabbri, 2003), Australia (Chiswick \& Miller, 1995, 2003), Germany (Dustman, 1994), Netherlands (Van Tubergen \& Kalmijn, 2009) and Israel (Mesch, 2003; Lang \& Siniver, 2006), and the role of English in developing countries is much less researched, partly for the scarcity of data on language use (Chiswick, 2008). While some scholars have partly bridged such gaps by examining the economic returns of learning English in Puerto Rico (Angrist et al., 2008), South Africa (Casale \& Posel, 2011), and India (Azam et al., 2013), the limited work hardly matches the great popularity of English learning in developing countries, and findings from those special countries, which are historically, politically and socially tied with English-speaking countries, can be hardly generalized into other developing countries. Especially, an obvious English boom, which even makes English the lingua franca in pan-Asian communication (Newton, 2015), has emerged in Asian countries (Bolton, 2008; Hashim et al., 2014; Kirkpatrick, 2014, 2015), such as China (Wu, 2001; Wolff, 2010; Wei \& Su, 2015; Bolton \& Graddol, 2012; Botha, 2014; Huang, 2016), Japan (Le Ha, 2013; Abe, 2013; Inagawa, 2015), South Korea (Byean, 2015; Jeon, 2012a, 2012b; Ahn, 2015), Indonesia (Zein, 2017), the Philippines (Tupas \& Salonga, 2016) and Vietnam (Nguyen, 2017), making those countries and Asia an excellent context for the study of English-related research (Wei \& Su, 2015). It is believed to be highly related to globalization and economic development (Nguyen, 2017), and with the people's improved English proficiency, this global language is playing an increasingly important role, not only in industries, businesses and workplaces (Vandenbroucke, 2016), but also people's personal lives (Wei \& Su, 2015; Botha, 2014). However, little empirical work has been conducted to offer any solid explanation to related phenomena.

To fill such gaps, the current research is set in the context of East and Southeast Asia, and tries to examine the influence of English proficiency on personal accomplishment with large-scale cross-nation data. While personal accomplishment is influenced by many factors at different levels, we assume, from the perspective of linguistic capital, that English proficiency is one of them. Obviously, as many other complicated socio-economic linkages, the focal relationship is complex and contextual, depending on various factors. To exploit and explain the inherent mechanisms, among all the possible influential factors, we further examine the mediating role of income, career development and quality of life as well as the moderating role of international involvement in the focal relationship. The discussion on the mediating role is partly in response to the extensive literature on the linkage between language skills and income, and is expected to expand and enrich our understanding of both direct and indirect economic returns of English proficiency. The discussion about the role of international exposure is taking the actual usage of English as a second language into consideration, and is expected to find out under what conditions English proficiency exerts its influence on personal accomplishment.

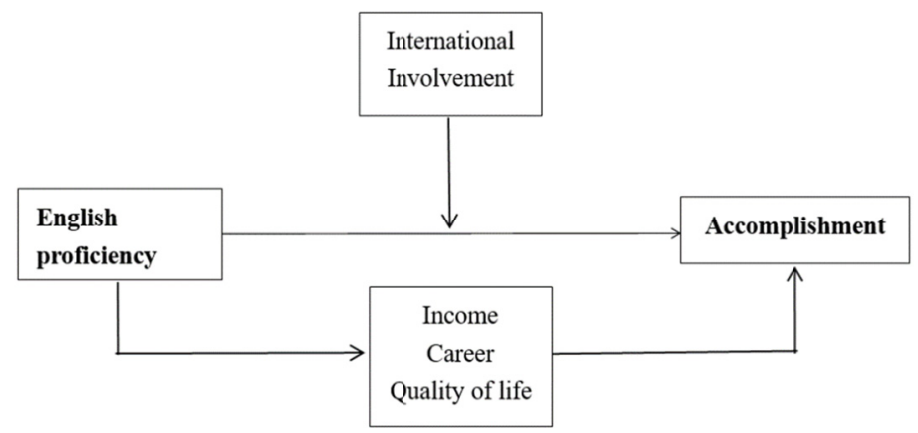

Figure 1. Theoretical model 


\section{Theoretical Foundations and Hypotheses}

\subsection{English Proficiency and Personal Accomplishment}

Personal accomplishment generally refers to one's feelings of competence and successful achievement in work and life (Maslach et al., 1996; Bang \& Reio, 2017). While few previous studies have ever directly discussed the relationship between English proficiency and one's accomplishment, we can infer from extant literature that the former probably positively influence the latter in some possible ways.

First, as explored and examined by an extensive literature, English proficiency increases one's income, and thus promotes personal accomplishment. Early empirical studies of economic linguistics investigated the role of English learning in immigrants' assimilation into local areas, and confirmed in different national contexts, such as Canada (Vaillancourt, 1996; Breton, 1998), United States (Bloom \& Grenier, 1996; Davila \& Mora, 2000), Australia (Chiswick \& Miller, 1995, 2003), Germany (Dustman, 1994) and Israel (Lang \& Siniver, 2006), that immigrants that acquired English, as a local or non-local language, earned higher income than those with lower English proficiency (Carliner, 2000; Chiswick \& Miller, 2003; Dustmann \& Fabbri, 2003). Especially, Chiswick and Miller $(1995,2003,2010,2015)$ have conducted a series of studies and investigated different groups of immigrants, men and women, with legal or illegal movement, as well as local residents, and further generalized the positive relationship between English proficiency and income with cross-cultural database. While the academic attention to the domestic market is relatively sparse, the limited work also indicates a positive linkage between English proficiency and income. For instance, English competence is proved to bring impressive premiums in countries with a colonial past, such as India (Munshi \& Rosenzweig, 2006; Azam et al., 2013; Chakraborty \& Bakshi, 2016) and South Africa (Levinsohn, 2007). As an important economic indicator of wealth, well-being and achievement, the increase of income usually leads to the enhancement of accomplishment.

Second, English proficiency positively influences personal accomplishment by enabling one to access and seize opportunities in the globalized economy, and thus promote one's career development (Vandenbroucke, 2016) and professional lives (Grosse, 2004; Wei \& Su, 2015; Botha, 2014). Globalization is one of the most important social and economic trends in recent decades, and as it progresses, acquiring English as a global language has long become a valuable resource, and more and more jobs present explicit requirements for English proficiency (Bloch, 1995; Warschauer, 2000; Markee, 2000), which means that those with strong English language competence easily stand out in the job market. Moreover, with the language skill permeating into the basic career competence of knowing how, why and whom, those with good language skills are able to cross boundaries and demonstrate high levels of career mobility, both psychologically and physically (Itani et al., 2015). Obviously, as companies get more international, people with high English proficiency and the resulted mobility, compared with others, enjoy better opportunities to accomplish more in their career and professional lives (Peltokorpi \& Vaara, 2012; Itani et al., 2015).

Third, in addition to income and career, English proficiency improves one's quality of life, and thus positively impacts personal accomplishment. Personal accomplishment comes from both work and life, and high quality of life is an essential source of one's accomplishment. English proficiency generally improves one's quality of life from three aspects. First, with higher income, people with English proficiency usually have kept greater financial flexibility and freedom, and are able to improve their quality of life by financially meeting basic and special material needs, such as affording comfortable housing, branded products and even some luxuries. Second, English proficiency also improves one's quality of life mentally, with access to good education and career development. Nowadays, similar to companies, universities and post-graduate programs usually assess the students' language skills for admission (Bolton \& Graddol, 2012). Third, English learning broadens one's international horizon (Wolff, 2010), and thus enables good learners to improve their quality of life with enriched understanding of life from other cultures (Prodromou, 1992). Moreover, in some non-English-speaking countries, English has already become an important element in popular culture and is commonly and creatively employed in cultural and entertainment activities (Botha, 2014; Zhou \& Moody, 2017; Fallatah, 2017), and thus good English learners are able to improve life enjoyment with access to English-related activities.

While English proficiency may also promote one's accomplishment in other ways, the three ways discussed above, which, to some extent, intersect, interact and interrelate with one another, are among the primary ones as important mediators. Therefore, we propose the following hypotheses:

H1: English proficiency positively influences personal accomplishment.

H2: The relationship between English proficiency and personal accomplishment is partly mediated by income, career development and quality of life. 


\subsection{The Moderating Role of International Involvement}

Extant literature shows that the relationship between English proficiency and income is influenced by other factors, such as gender, education and occupation (Munshi \& Rosenzweig, 2006; Azam et al., 2013; Chakraborty $\&$ Bakshi, 2016). Among all the possible influential factors, we focus on international involvement, which refers to one's participation and involvement in international or related activities, such as being expatriated overseas, communicating with international contacts, traveling to foreign countries, and searching and receiving international information. Our focus is based on two primary reasons. For one thing, considering the background of English fever, a most important contextual factor is globalization (Warschauer, 2000; Block \& Cameron, 2002; Kubota \& McKay, 2009; Gao et al., 2009), and the globalized environment exposes people to all kinds of international activities, and the increased international involvement naturally influence the acquisition of EFL/ESL (Warschauer, 2000; Markee, 2000; Song, 2011) and the consequences of such behaviors. For another, considering the actual usage of English, international involvement gives language learners opportunities to or even forces them to use the acquired foreign languages (Kubota \& McKay, 2009; Neeley \& Dumas, 2016), and meanwhile, allows them to stand out and make special achievements with English proficiency. Thus, we assume that international involvement positively moderates the relationship between English proficiency and personal accomplishment.

First, international involvement gives people opportunities to get higher income with their English skills. Working for multinationals, oversea expatriation, expanding international business, all such activities allow excellent English learners to enjoy generous payment with their good language skills (Azam et al., 2011; Chakraborty \& Bakshi, 2016). Some well-paid language-related professionals, like translators, interpreters and international business agents, heavily rely on international involvement to ensure their income (Dam \& Zethsen, 2011). On the contrary, for those whose work is hardly related to any international activities, it is difficult for them to get premiums even if they hold outstanding foreign language skills.

Second, international involvement gives good English learners opportunities to outstand in their professional lives (Gao et al., 2007; Vandenbroucke, 2016). In addition to income increase, the ability to participate and perform well in international activities differentiates the proficient language learners from their colleagues, not only bringing them access to good career opportunities with language requirements, but also enabling them to accomplish more with improved mobility and expanded scope (Itani et al., 2015). Moreover, the cultural skills picked up in international activities also strengthens the effect of language skills as important and necessary compliments.

Finally, international involvement promotes people to improve their quality of life with English skills by increasing their international exposure and inter-cultural knowledge (Prodromou, 1992). While English learning helps learners to acquire cross-cultural information and broaden international horizon (Holliday, 2013), direct participation and involvement in international activities greatly accelerates the learning pace and effectively strengthens the learning output. During such a process, people's understanding of quality life enriches with international perspectives and updates, which in turn guide them to improve their own life with international standards and approaches.

Therefore, we believe that, international involvement strengthens the relationship between English proficiency and personal accomplishment by enabling and promoting the impact mechanisms, and present the following hypothesis:

H3: International involvement positively moderates the relationship between English proficiency and personal accomplishment.

\section{Method}

\subsection{Study Sample and Data Collection}

To explore the focused research questions with empirical evidences, we conduct statistical analyses with the database of AsiaBarometer Survey 2006 and 2007. The AsiaBarometer series survey, which was initiated in 2003 and carried out in 6 successive years until 2008 jointly by the Tokyo Satellite Office, University of Niigata Prefecture and the Research and Information Center for Asian Studies, Institute of Oriental Culture, University of Tokyo, "represents the largest ever comparative survey in Asia, covering East, Southeast, South and Central Asia", and "focuses on daily life of ordinary people and their relationships to family, neighborhood, workplace, social and political institutions and market place" (AsiaBarometer, 2015, see the official website of the survey: https://www.asiabarometer.org/). The questionnaires were designed with a common research framework and country-wide face-to-face surveys were conducted in major Asian countries. 
Due to the availability of the latest data, we examine the proposed hypotheses with data from the 2006 and 2007 surveys. The AsiaBarometer 2006 project covered China, Hong Kong of China, Japan, Korea, Singapore, Taiwan of China and Vietnam, and the 2007 project covered Cambodia, Indonesia, Laos, Malaysia, Myanmar, the Philippines, and Thailand. The survey covered such topics as quality of life, happiness, religion, governance, international alignments, globalization, mass media, identity and democratic consolidation, which enables the current research to measure English proficiency, personal accomplishment, international involvement and other major variables with large-scale data. The questionnaires were formulated in English, and were translated into local languages by local survey organizations, and were further checked through back translation. In 2006, all adults aged 20-59, and in 2007, all adults aged 20-69, were targeted with multi-stage-stratified random sampling and quota sampling, and around 1000 people were sampled in each country (2000 in mainland China). Face-to-face interviews were conducted to ensure the quality of data collection. 8070 valid cases were obtained in 2006, and 7012 were obtained in 2007. Thus, 15082 cases form our final sample.

\subsection{Measures}

Independent variable, English proficiency. English proficiency is measured with self-reported data. Respondents were asked how well they spoke English: 1 = "not at all", 2 = "very little", 3 = "I can speak it well enough to get by in daily life", and 4 = "I can speak English fluently".

Dependent variable, accomplishment. Respondents were asked how much they felt they were accomplishing what they want out of their life: 1 = "a great deal", 2 = "some", 3 = "very little", and 4 = "none".

Table 1. Component matrix of the integrated mediator

\begin{tabular}{ll}
\hline Items & Component \\
\hline Standard of living & 0.804 \\
Household income & 0.806 \\
Education & 0.671 \\
Job & 0.727 \\
Housing & 0.664 \\
\hline
\end{tabular}

Note. The extraction method is Principal Component Analysis; the Kaiser-Meyer-Olkin Measure of Sampling Adequacy is 0.799; the cumulative \% of variance is 54.294; in Bartlett's Test of Sphericity, Approx. Chi-Square is 19906.365, the degree of freedom is 10, and the significance level is 0.000 .

Mediators, income, career development and quality of life. Respondents were asked how satisfied or dissatisfied they were with specific aspects of their life. 5-point Likert scale was used to measure their satisfaction of each aspect. 1 represents "very satisfied", 2 = "somewhat satisfied", 3= "neither satisfied nor dissatisfied", $4=$ "somewhat dissatisfied", and 5 = "very dissatisfied". As discussed before, as mediators, income, career development and quality of life are interrelated with one another. While job and education indicate one's career development, housing, household income and standards of living indicator one's income, all these factors also reflect one's quality of life. Considering the overlapping and interaction of the three variables and their shared mediating role, we conduct a factor analysis to the satisfaction of the 5 aspects, and take the extracted factor as a proxy of all the three mediators. As is shown in table 1, the extracted factor can well represent the KMO is 0.803 , and the accumulative $\%$ of variance is 55.571 , which shows that the extracted factor can well represent the 5 items.

Moderator, international involvement. Respondents were asked to if the following statements applied to them: "(1) A member of my family or a relative lives in another country; (2) I have traveled abroad at least three times in the past three years, on holiday or for business purposes; (3) I have friends from other countries ; (4) I often watch foreign-produced programs on TV; (5) I often communicate with people in other countries via the Internet or email; and (6) My job involves contact with organizations or people in other countries." If a statement applies to the respondent, it is coded as 1 , otherwise as 0 . To incorporate all the activities, we sum up values of all the 6 items, and take it as proxy of international involvement.

Control variables. Extant literature show that the effect of English proficiency is influenced by some socio-demographic variables, such as gender (Munshi \& Rosenzweig, 2006; Azam et al., 2013; Chakraborty \& Bakshi, 2016). In regression analysis, we control the impacts of such variables, including gender, education, age, marital status, occupation status, and the number of families that work and earn an income. Gender is measured with a dummy variable, male-coded as 1 , and female as 0 . Education is measured with the highest education a respondent had completed, "no formal education" or "elementary/junior school" coded as 1, "high school" coded 
as 2, "professional/technical school" or "university/graduate school" coded as 3. Marital status is measured with a dummy variable, married coded as 1 , and all the other status as 0 . Occupation status is measured with a dummy variable, employed or self-employed coded as 1 , and unemployed coded as 0 . The number of family with an income is measured with continuous variables as reported by the respondents.

\subsection{Data Analysis}

We use IBM SPSS 22.0 to conduct the required statistical analyses. First, we conduct a factor analysis to extract the integrated mediator of income, career development and quality of life from 5 considered items. Second, we conduct descriptive and correlation analysis to all the variables. Third, to examine the mediation of income, career development and quality of life, we first respectively examine the direct influence of English proficiency on accomplishment, the influence of English proficiency on the integrated variable of income, career development and quality of life, and the influence of the integrated mediator on accomplishment, and then check if the influence of English proficiency on accomplishment is weakened when the effect of mediator is controlled. And finally, hierarchical regression analysis is conducted to examine the moderating effect of international involvement on the relationship between English proficiency and accomplishment.

\section{Results}

Table 2. Socio-demographic characteristics of the sample

\begin{tabular}{llllllll}
\hline Characteristic & Value & $\mathrm{N}$ & $\%$ & Characteristic & Value & $\mathrm{N}$ & $\%$ \\
\hline Country & China & 2000 & 13.3 & Education & Low & 6547 & 43.4 \\
& HK China & 1000 & 6.6 & & Mid & 4846 & 32.2 \\
& Japan & 1003 & 6.7 & & High & 3675 & 24.4 \\
& Korean & 1023 & 6.8 & Number of families that & None & 278 & 1.8 \\
& Singapore & 1038 & 6.9 & work and earn an income & 1 person & 4798 & 31.8 \\
& TW China & 1006 & 6.7 & & 2 persons & 6397 & 42.4 \\
& Vietnam & 1000 & 6.6 & & 3 persons & 2213 & 14.7 \\
& Malaysia & 1000 & 6.6 & & 4 persons & 982 & 6.5 \\
& Indonesia & 1000 & 6.6 & & 5 persons & 261 & 1.7 \\
& Philippines & 1000 & 6.6 & & 6 persons & 104 & 0.7 \\
& Thailand & 1000 & 6.6 & & $\geq 7$ persons & 41 & 0.3 \\
& Myanmar & 1000 & 6.6 & Marriage & Other & 4361 & 28.9 \\
& Cambodia & 1012 & 6.7 & & Married & 10721 & 71.1 \\
& Laos & 1000 & 6.6 & employment & Self-employed & 3053 & 20.3 \\
& $20-29$ & 3919 & 26.0 & & Employed & 6982 & 46.3 \\
& $30-39$ & 4120 & 27.3 & & Unemployed & 5035 & 33.4 \\
& $40-49$ & 3395 & 22.5 & Gender & Female & 7862 & 52.1 \\
& $50-59$ & 2308 & 15.3 & & Male & 7220 & 47.9
\end{tabular}

\subsection{Socio-Demographic Characteristics}

As is shown in Table 2: all the 15082 respondents are almost evenly sampled in 14 countries or areas (about 1000 in each), except for Mainland China ( $\mathrm{N}=2000) ; 52.1 \%$ of the respondents are female, and $47.9 \%$ are male; $26.0 \%$ of them were at the age range from 20 to $29,27.3 \%$ from 30 to $39,22.5 \%$ from 40 to $49,15.3 \%$ from 50 to 59 , and only $8.9 \%$ from 60 to $69 ; 71.1 \%$ of them were married, with $28.9 \%$ single, divorced or widowed; $43.4 \%$ of them received no formal education or just graduated from elementary or junior school, $32.2 \%$ graduated from high school, and $24.4 \%$ graduated from professional/technical school or university/graduate school; $20.3 \%$ of them are self-employed, $46.3 \%$ employed, and $33.4 \%$ unemployed; as to family income structure, $42.4 \%$ of respondents had 2 family members who worked and earned an income, $31.8 \%$ had only $1,14.7 \%$ had 3, 9.2\% had 4 or more, and $1.8 \%$ had no family with job and income. Such results of socio-demographic analysis show that the sample distribution well reflects the socio-demographic characteristics of the sampled Asian regions in the first 10 years of the new century, and the collected data are valid and reliable for further statistical analyses. 


\subsection{Descriptive Statistics and Correlation of Variables}

Table 3. Descriptive statistics and correlation matrix

\begin{tabular}{|c|c|c|c|c|c|c|c|c|c|c|c|c|c|c|c|}
\hline & $\mathrm{N}$ & Min & Max & Mean & Std. D. & 1 & 2 & 3 & 4 & 5 & 6 & 7 & 8 & 9 & 10 \\
\hline Accomp. & 15022 & 1 & 4 & 2.25 & 0.716 & 1 & & & & & & & & & \\
\hline EnglishP & 14937 & 1 & 4 & 1.85 & 0.874 & $-.124 * *$ & 1 & & & & & & & & \\
\hline ICDQL & 14432 & -2.1 & 3.6 & 0 & 1 & $.403 * *$ & $-.237 * *$ & 1 & & & & & & & \\
\hline InternationalI & 15082 & 0 & 6 & 1.03 & 1.146 & $-.133 * *$ & $.436^{* *}$ & $-.173 * *$ & 1 & & & & & & \\
\hline Gender & 15082 & 0 & 1 & 0.48 & 0.5 & 0.012 & $.055^{* *}$ & -0.005 & $.020^{*}$ & 1 & & & & & \\
\hline Age & 15082 & 1 & 5 & 2.54 & 1.268 & -0.015 & $-.246^{* *}$ & $.046^{* *}$ & $-.100 * *$ & $.023 * *$ & 1 & & & & \\
\hline MaritalS & 15082 & 0 & 1 & 0.71 & 0.453 & $-.075 * *$ & $-.186^{* *}$ & -0.013 & $-.065^{* *}$ & $-.028 * *$ & $.327 * *$ & 1 & & & \\
\hline Education & 15068 & 1 & 3 & 1.81 & 0.801 & $-.077 * *$ & $.474 * *$ & $-.141 * *$ & $.186^{* *}$ & $.088 * *$ & $-.286^{* *}$ & $-.210 * *$ & 1 & & \\
\hline OccupationS & 15070 & 0 & 1 & 0.67 & 0.472 & $-.023 * *$ & $.054 * *$ & $-.047 * *$ & $.049 * *$ & $.310 * *$ & $-.079 * *$ & 0.015 & $.061 * *$ & 1 & \\
\hline NWFM & 15074 & 1 & 8 & 3.02 & 1.065 & $-.046^{* *}$ & $.032 * *$ & $-.078 * *$ & $.033 * *$ & $.033 * *$ & $-.108 * *$ & $-.087 * *$ & $.060 * *$ & $.215^{* *}$ & 1 \\
\hline
\end{tabular}

Note. Pearson Correlation Analysis; Significance level: ** $\mathrm{p}<0.01$ level, $* \mathrm{P}<0.05$ (2-tailed).

EnglishP: English proficiency; ICDQL: the integrated variable of income, career development and quality of life; InternationalI: International Involvement; MaritalS: Marital Status; OccupationS: Occupation Status; NWFM: Number of Working Family Member.

Table 3 presents descriptive statistics and correlations of variables in the research. As is shown in this table, the dependent variable happiness is highly correlated with the independent variable, mediator, moderators, and most of the control variables. Such linkages were further examined in regression analyses. While most of the variables are correlated with one another, the highest coefficient is 0.436 , lower than 0.5 , which shows that multicollinearity is not serious in the current research. We further conduct the variance inflation factor (VIF) analysis to all the variables, and collinearity statistics show that the highest VIF is just 1.623, much lower than 10 , which also shows that multicollinearity is not a problem.

\subsection{English Proficiency and Personal Accomplishment}

Table 4 presents the regression estimates on accomplishment. Model 1 estimates the influence of control variables, and model 2-1 shows the influence of English proficiency. Both models are statistically significant. As is shown in model 1, the regression coefficients of gender, age, marital status, education, and number of working family members are respectively $0.025(\mathrm{P}<0.01), 0.019(\mathrm{P}<0.05),-0.093(\mathrm{P}<0.01),-0.101(\mathrm{P}<0.01)$ and $-0.048(\mathrm{P}<0.01)$, and all are statistically significant. Some interesting conclusions can be inferred from such results: 1) the female generally accomplish more than the male; 2) the younger generally accomplish more than the older; 3 ) the married accomplish more than those who are single, divorced or widowed; 4) people with better education generally accomplish more; and 5) families with more members that work and earn money generally accomplish more. But the regression coefficient of occupation status is not statistically significant $(-0.014, \mathrm{P}=$ 0.110 ), which surprisingly shows that accomplishment is not significantly related to occupation status. A possible explanation is that some of the employed and self-employed might get depressed or disappointed at their work, while some of the unemployed might find other ways to accomplish what they want. Such an explanation can be partly proved when we prove the mediation of income, career development and quality of life, which includes job satisfaction as an important factor.

After the entry of English proficiency, $\mathrm{R}^{2}$ significantly increases by $0.013(\mathrm{P}<0.01)$ in model $2-1$, and the regression coefficient of the independent variable is $-0.128(\mathrm{P}<0.01)$, and statistically significant. The result shows that English proficiency positively influences one's accomplishment, and hypothesis 1 is supported. 
Table 4. Regression estimates on accomplishment, mediation of income, career development and quality of life and moderation of international involvement

\begin{tabular}{|c|c|c|c|c|c|c|c|c|}
\hline & \multicolumn{6}{|c|}{ Accomplishment } & \multicolumn{2}{|l|}{ ICDQL } \\
\hline & M1 & M2-1 & M3 & M2-2 & M5-1 & M5-2 & M4-1 & M4-2 \\
\hline Gender & $0.025 * *$ & $0.026^{* *}$ & $0.017 *$ & $0.018^{*}$ & $0.025 * *$ & $0.025^{* *}$ & 0.016 & $0.018^{*}$ \\
\hline Age & $-0.019^{*}$ & $-0.033 * *$ & $-0.023 * *$ & $-0.028 * *$ & $-0.033 * *$ & $-0.036 * *$ & 0.014 & -0.009 \\
\hline MaritalS & $-0.093 * *$ & $-0.102 * *$ & $-0.075^{* *}$ & $-0.078 * *$ & $-0.101 * *$ & $-0.102 * *$ & $-0.051 * *$ & $-0.067 * *$ \\
\hline Education & $-0.101 * *$ & $-0.047 * *$ & $-0.042 * *$ & $-0.026^{* *}$ & $-0.049 * *$ & $-0.045 * *$ & $-0.142 * *$ & $-0.044 * *$ \\
\hline Employed & -0.014 & -0.012 & -0.006 & -0.005 & -0.009 & -0.01 & $-0.027 * *$ & $-0.019 *$ \\
\hline NWFM & $-0.048 * *$ & $-0.053 * *$ & $-0.024 * *$ & $-0.027 * *$ & $-0.051 * *$ & $-0.05^{* *}$ & $-0.067 * *$ & $-0.072 * *$ \\
\hline InternationalI & & & & & $-0.097 * *$ & $-0.116^{* *}$ & & \\
\hline EnglishP & & $-0.128 * *$ & & $-0.042 * *$ & $-0.084 * *$ & $-0.094 * *$ & & $-0.227 * *$ \\
\hline ICDQL & & & $0.395^{* *}$ & $0.386^{* *}$ & & & & \\
\hline InternationalI*EnglishP & & & & & & $0.04 * *$ & & \\
\hline $\mathrm{R} 2$ & 0.018 & 0.031 & 0.17 & 0.171 & 0.039 & 0.04 & 0.028 & 0.067 \\
\hline R2 change & 0.018 & 0.013 & 0.152 & 0.001 & 0.008 & 0.001 & 0.028 & 0.039 \\
\hline $\mathrm{F}$ & $45.343 * *$ & $67.612 * *$ & $420.161 * *$ & $366.065 * *$ & $74.34 * *$ & $67.959 * *$ & $68.132 * *$ & $146.299 * *$ \\
\hline df & 6 & 7 & 7 & 8 & 8 & 9 & 6 & 7 \\
\hline Gender & $0.025 * *$ & $0.026 * *$ & $0.017 *$ & $0.018^{*}$ & $0.025 * *$ & $0.025 * *$ & 0.016 & $0.018^{*}$ \\
\hline
\end{tabular}

\subsection{Mediation of Income, Career Development and Quality of Life}

Table 3 also presents the regression estimates of the mediating role of income, career development and quality of life. Model 2-1 and model 3 respectively estimates the influence of the independent variable and the mediator on accomplishment, model 4-1 and 4-2 estimates the influence of control variables and English proficiency on the integrated mediator, and model 2-2 estimates the influence of English proficiency after controlling the effect of leisure satisfaction. All the models are statistically significant.

In model 4-2, the regression coefficient of English proficiency is $-0.227(\mathrm{P}<0.01)$ and statistically significant, showing that English proficiency positively influences the integrated variable in model 3 , the regression coefficient of the integrated variable is $0.395(\mathrm{P}<0.01)$ and statistically significant, showing that the integrated variable positively and greatly influences one's accomplishment. Based on that, in model $2-2$, we controlled the effect of the integrated variable and re-examined the influence of English proficiency on accomplishment for comparison. The regression coefficients of English proficiency in model 2-1 and model 2-2 are respectively $-0.128(\mathrm{P}<0.01)$ and $-0.042(\mathrm{P}<0.01)$, which shows that the positive influence is partially mediated by income, career development and quality of life. Thus, hypothesis 2 is supported.

\subsection{Moderation of International Involvement}

Table 4 also presents the regression estimates of the moderating role of international involvement in the relationship between English proficiency and one's accomplishment. Based on model 2-1, model 5-1 examines the direct influence of international involvement on accomplishment, and model 5-2 examines the moderation of international involvement. All the models are statistically significant.

In model $5-1$, the regression coefficients of international involvement are $-0.097(\mathrm{P}<0.01)$ and statistically significant, showing that international involvement positively influences one's accomplishment. As to the moderating effect, as is shown in model 5-2, the regression coefficient of the interaction term of international involvement and English proficiency is $0.04(\mathrm{P}<0.01)$ and statistically significant, showing that international involvement positively moderates the influence of English proficiency on accomplishment. Thus, hypothesis 3 is supported.

\subsection{Discussion}

The empirical results have supported all the proposed hypotheses, and proved the influence of English proficiency on personal accomplishment, as well as the mediating role of income, career development and quality of life, and the moderating role of international involvement in the focal relationship. Such findings greatly enrich our understanding about why people learn English and how they benefit from English learning. Especially, the instrumentality of English learning is disclosed and empirically confirmed.

For one thing, the positive influence of English proficiency clearly and convincingly demonstrates the instrumentality of language learning, and the mediating role of income, career development and quality of life 
further disclose and decompose its instrumentality. From the perspective of language policy and language planning, language teaching and learning is a vital part of acquisition planning (Hornberger, 2009; Ramanathan \& Morgan, 2007; Hult, 2012), and play a critical role in the implementation and success of language-related policies. However, political or policy consideration is inadequate in explaining the English fever around the world. English learning may be driven by both integrative motivations, such as intrinsic interest, learning situation, information medium and social responsibility, and instrumental motivations, such as immediate achievement, going abroad, and individual development (Gardner \& Lambert, 1972; Gao et al., 2007; Song, 2011). The current study empirically maintains that it is the instrumentality of English learning that essentially motivates people to actively get engaged in language acquisition. Supplementary to previous discussions about the relationship between English proficiency and income (Chiswick \& Miller, 1995, 2003; Angrist et al., 2008; Casale \& Posel, 2011; Azam et al., 2013), this paper points out that, the instrumentality of English proficiency is not only embedded in its effect on income, career and quality of life, but also in its further influence on personal accomplishment. Moreover, by exploiting and examining the instrumental functions of English, this paper also serves as a positive response to the human capital assumption (Grin, 1996) in economic linguistics.

For another, the positive moderating role of international involvement shows that the human capital of language competence is embedded in related behaviors and that the instrumentality of English learning is influenced and even shaped by such behaviors and relevant contexts. For immigrants, acquiring English as the local language or the dominant foreign language in local areas promotes both social and economic assimilation into the local areas (Vaillancourt, 1996; Breton, 1998; Dustmann \& Fabbri, 2003; Van Tubergen \& Kalmijn, 2009); for non-immigrants in countries or areas where English has been dominant for colonial history, acquiring that language is a must for prosperity in both life and work (Azam et al., 2013); and, for non-immigrants in countries or areas with no such colonial pasts or any dominant foreign language, with the prominent progress of globalization, acquiring English as a global language enable them to participate in international activities and accomplish more in both work and life. Despite sharp contextual differences, English learners from all the contexts, are all motivated to acquire the target language and given the opportunities to use it. While the behavior of learning, which produces the human capital, is greatly driven by instrumental factors (Gardner \& Lambert, 1972; Gao et al., 2007), it is the behavior of using the acquired language and the allowing contexts that enable the learner to achieve those instrumental purposes.

\section{Conclusion}

With large-scale survey data from 14 East and Southeast Asian countries and areas, this paper examines the influence of English proficiency on personal accomplishment, and especially, explores the role of income, career development, quality of life as well as international involvement in the focal relationship. Empirical results show that English proficiency positively impacts personal accomplishment, and that the effect is partly mediated by the integrated variable of income, career development and quality of life, and is positively moderated by international involvement.

With such findings, the current paper presents important theoretical and practical implications. From the theoretical perspective, it contributes to the extant literature in three aspects. First, this paper further confirms the influence of English proficiency on personal accomplishment with large-scale data from different countries and areas, and thus expand and generalize findings from extant literature. While previous studies have generally taken income as the end of the effect chain, and are more or less limited by data within the national boundary, the current study expands the chain to personal accomplishment, which stands high atop Maslow's hierarchy of needs (Maslow, 1943) and well explains people's motivation in English learning, and proves the linkage with valid data from 14 countries and areas. Second, with a discussion about the mediation of income, career development and quality of life, and the moderation of international involvement, this paper deepens our understanding about how English proficiency exerts influence on accomplishment and related factors, and thus contributes to the literature on English proficiency, especially the literature on its effect. Finally, while prior studies were generally set in the immigration labor market in developed countries or the domestic market of a few developing countries with colonial past, we set the current study in the domestic market of Asian countries and areas, and manages to explore and explain the English learning boom in Asia. Especially, while in most of the investigated areas, English has never been as dominant as national lingua francs in history and today, the instrumentality of learning English still exists. Therefore, this paper not only enriches extant literature with generalized empirical findings and in-depth analysis, but also paves ways for future work by extending the research chain and expanding the research context.

This paper also presents important practical implications, mainly for English learning and teaching as well as acquisition planning. With valid empirical data, this paper discloses and confirms the positive effect of English 
proficiency on personal accomplishment, and thus motivates English learners to improve their language skills for the instrumental ends. The motivational instrumentality will be quite useful and effective in the education of FEL/ESL, both learning and teaching. Furthermore, the positive moderation of international involvement shows that it is necessary and useful to expose English learners to all kinds of international activities, which give them opportunities not only to improve their language skills, but also to strengthen the instrumental functions of the acquired language competence. Globalization makes it possible and quite convenient to supply learners with such opportunities, and drivers EFL/ESL practitioners to develop socially relevant pedagogies (Markee, 2000; Warschauer, 2000) by employing such opportunities.

It must be noted that there are limitations in the current study. First of all, for the design of the AsiaBarometer Survey, measurements of the major variables are based on the respondents' subjective assessment. While the Likert-type scale is widely proved valid and reliable and frequently employed in operationalizing various social variables (Matell \& Jacoby, 1972; Maurer \& Pierce, 1998), objective evaluation of English proficiency, personal accomplishment and other important variables will surely improve the validity and reliability of the research. Also, for the limited availability of AsiaBarometer database, our empirical analysis is just based on the data from the 2006 and 2007 surveys. While the relationship between English proficiency and personal accomplishment is quite stable and may even get strengthened with the progress of globalization, updated data will surely provide evidences that are more compatible with the social and economic dynamics of the research context and bring us more enriched understanding of the focal relationship. Thus, further work is expected to improve such limitations.

\section{Acknowledgments}

This study is supported by the National Natural Science Foundation of China (Project No. 71872165; 71402163), the Social Science and Humanities Research Foundation of Chinese Ministry of Education (18YJC630241), and the Research Foundation of China's Language Commission (YB135-95). All views expressed are those of the authors and not of the sponsoring organizations.

\section{References}

Abe, \& Emiko. (2013). Communicative language teaching in Japan: current practices and future prospects. English Today, 29(02), 46-53. https://doi.org/10.1017/S0266078413000163

Ahn, H. (2015). Assessing proficiency in the National English Ability Test (NEAT) in South Korea. English Today, 31(01), 34-42. https://doi.org/10.1017/S0266078414000522

Angrist, J. D., \& Lavy, V. (1997). The Effect of a Change in Language of Instruction on the Returns to Schooling in Morocco. Journal of Labor Economics, 15(1, Part 2), S48-S76. https://doi.org/10.1086/209856

Angrist, J., Chin, A., \& Godoy, R. (2008). Is Spanish-only schooling responsible for the Puerto Rican language gap? Journal of Development Economics, 85(1), 105-128. https://doi.org/10.1016/j.jdeveco.2006.06.004

Azam, M., Chin, A., \& Prakash, N. (2013). The returns to English-language skills in India. Economic Development and Cultural Change, 61(2), 335-367. https://doi.org/10.1086/668277

Bloch, B. (1995). Career enhancement through foreign language skills. International Journal of Career Management, 7(6), 15-26. https://doi.org/10.1108/09556219510098073

Block, D., \& Cameron, D. (Eds.). (2002). Globalization and language teaching. Routledge. https://doi.org/10.4324/9780203193679

Bloom, D. E., \& Grenier, G. (1996). Language, employment, and earnings in the United States: Spanish-English differentials from 1970 to 1990. International Journal of the Sociology of Language, 121(1), 45-68. https://doi.org/10.1515/ijsl.1996.121.45

Bolton, K. (2008). English in Asia, Asian Englishes, and the issue of proficiency. English Today, 24(2), 3. https://doi.org/10.1017/S026607840800014X

Bolton, K., \& Graddol, D. (2012). English in China today. English Today, 28(3), 3. https://doi.org/10.1017/S0266078412000223

Bolton, K., \& Botha, W. (2015a). Researching English in contemporary China. World Englishes, 34(2), 169-174. https://doi.org/10.1111/weng.12131

Bolton, K., \& Botha, W. (2015b). English in China's universities: Past and present. World Englishes, 34(2), 190210. https://doi.org/10.1111/weng. 12133

Botha, W. (2013). English - medium instruction at a university in Macau: Policy and realities. World Englishes, 
32(4), 461-475. https://doi.org/10.1111/weng.12053

Botha, W. (2014). English in China's universities today. English Today, 30(01), 3-10. https://doi.org/10.1017/S0266078413000497

Breton, A. (1998). Economic Approaches to Language and Bilingualism. Ottawa: Canadian Heritage.

Byean, H. (2015). English, Tracking, and Neoliberalization of Education in South Korea. TESOL Quarterly, 49(4), 867-882. https://doi.org/10.1002/tesq.257

Carliner, G. (2000). The Language Ability of U.S. Immigrants: Assimilation and Cohort Effects. International Migration Review, 34(1), 158-182. https://doi.org/10.1177/019791830003400107

Casale, D., \& Posel, D. (2011). English Language Proficiency and Earnings in a Developing Country: The Case of South Africa. Journal of Socio-Economics, 40(4), 385-393. https://doi.org/10.1016/j.socec.2011.04.009

Chakraborty, T., \& Bakshi, S. K. (2016). English language premium: Evidence from a policy experiment in India. Economics of Education Review, 50, 1-16. https://doi.org/10.1016/j.econedurev.2015.10.004

Chiswick, B. R. (2008). The economics of language: an introduction and overview. IZA Discussion Papers, No. 3568. Retrieved from http://nbn-resolving.de/urn:nbn:de:101:1-2008070230

Chiswick, B. R., \& Miller, P. W. (1995). The endogeneity between language and earnings: International analyses. Journal of Labor Economics, 13(2), 246-288. https://doi.org/10.1086/298374

Chiswick, B. R., \& Miller, P. W. (2003). The complementarity of language and other human capital: Immigrant earnings in Canada. Economics of Education Review, 22(5), 469-480. https://doi.org/10.1016/S0272-7757(03)00037-2

Chiswick, B. R., \& Miller, P. W. (2010). Occupational language requirements and the value of English in the US labor market. Journal of Population Economics, 23, 353-372. https://doi.org/10.1007/s00148-008-0230-7

Chiswick, B. R., \& Miller, P. W. (2015). International migration and the economics of language. In B. R. Chiswick \& P. W. Miller (Eds.), Handbook of the economics of international migration, (vol. 1A. pp. 211269). Amsterdam: North-Holland. https://doi.org/10.1016/B978-0-444-53764-5.00005-0

Crystal, D. (2012). English as a global language. Cambridge University Press. https://doi.org/10.1017/CBO9781139196970

Dam, H. V., \& Zethsen, K. K. (2011). The status of professional business translators on the Danish market: A comparative study of company, agency and freelance translators. Meta: Translators' Journal, 56(4), 976997. https://doi.org/10.7202/1011263ar

Dávila, A., \& Mora, M. T. (2000). English skills, earnings, and the occupational sorting of Mexican Americans along the US-Mexico border. International Migration Review, 133-157. https://doi.org/10.1177/019791830003400106

Dustmann, C. (1994). Speaking fluency, writing fluency and earnings of migrants. Journal of Population Economics, 7(2), 133-156. https://doi.org/10.1007/BF00173616

Dustmann, C., \& Fabbri, F. (2003). Language proficiency and labour market performance of immigrants in the UK. The Economic Journal, 113(489), 695-717. https://doi.org/10.1111/1468-0297.t01-1-00151

Gao, Y., Zhao, Y., Cheng, Y., \& Zhou, Y. (2007). Relationship between English learning motivation types and self - identity changes among Chinese students. Tesol Quarterly, 41(1), 133-155. https://doi.org/10.1002/j.1545-7249.2007.tb00043.x

Gardner, R. C. (2002). Social psychological perspective on second language acquisition. In R. Kaplan (Ed.), The Oxford handbook of applied linguistics (pp. 160-169). New York: Oxford University Press.

Gardner, R. C., \& Lambert, W. E. (1972). Attitudes and motivation in second language learning. Rowley, MA: Newbury House.

Grin, F. (1996). Economic approaches to language and language planning: An introduction. International Journal of the Sociology of Language, 121(1), 1-16. https://doi.org/10.1515/ijsl.1996.121.1

Grosse, C. U. (2004). The competitive advantage of foreign languages and cultural knowledge. The Modern Language Journal, 88(3), 351-373. https://doi.org/10.1111/j.0026-7902.2004.00234.x

Hashim, A., Yee, C. L., \& Pheak, T. P. (2014). English in higher education in Cambodia. World Englishes, 33(4), 498-511. https://doi.org/10.1111/weng.12110 
He, J. J., \& Chiang, S. Y. (2016). Challenges to English-medium instruction (EMI) for international students in China: A learners' perspective. English Today, 1-5. https://doi.org/10.1017/S0266078416000390

Holliday, A. (2013). The struggle to teach English as an international language. Oxford University Press.

Hornberger, N. H. (2009). Frameworks and models in language policy and planning. In T. Ricento (Ed.), An introduction to language policy: Theory and method (pp. 24-41). John Wiley \& Sons

Hu, Y. (2008). China's English language policy for primary schools. World Englishes, 27(3-4), 516-534. https://doi.org/10.1111/j.1467-971X.2008.00582.x

Huang, I. C. (2016). "Everybody learns English, and so do I": The dominance of English and its effects on individuals. English Today, 32(01), 28-34. https://doi.org/10.1017/S0266078415000504

Hult, F. M. (2012). English as a transcultural language in Swedish policy and practice. Tesol Quarterly, 46(2), 230-257. https://doi.org/10.1002/tesq.19

Hyejin, B., \& Thomas, G. R. Jr. (2017) Personal Accomplishment, Mentoring, and Creative Self-Efficacy as Predictors of Creative Work Involvement: The Moderating Role of Positive and Negative Affect. The Journal of Psychology, 151(2), 148-170. https://doi.org/10.1080/00223980.2016.1248808

Inagawa, M. (2015). Creative and Innovative Uses of English in Contemporary Japan. English Today, 31(03), 11-16. https://doi.org/10.1017/S026607841500019X

Itani, S., Järlström, M., \& Piekkari, R. (2015). The meaning of language skills for career mobility in the new career landscape. Journal of World Business, 50(2), 368-378. https://doi.org/10.1016/j.jwb.2014.08.003

Jeon, M. (2012a). Globalization of English teaching and overseas Koreans as temporary migrant workers in rural Korea. Journal of Sociolinguistics, 16(2), 238-254. https://doi.org/10.1111/j.1467-9841.2011.00527.x

Jeon M. (2012b). English immersion and educational inequality in South Korea. Journal of Multilingual and Multicultural Development, 33(4), 395-408. https://doi.org/10.1080/01434632.2012.661438

Jones, G. M. (2016). Policy and practice in the use of English in Brunei primary school classes. World Englishes, 35(4), 509-518. https://doi.org/10.1111/weng.12222

Kaiwar, V., \& Mazumdar, S. (2003). Antinomies of modernity: Essays on race, orient, nation. Durhan, NC: Duke University Press. https://doi.org/10.1215/9780822384564

Kamwangamalu, N. M. (2013). Effects of policy on English - medium instruction in Africa. World Englishes, 32(3), 325-337. https://doi.org/10.1111/weng.12034

Kang, H. S. (2012). English-only instruction at Korean universities: Help or hindrance to higher learning? English Today, 28(01), 29-34. https://doi.org/10.1017/S0266078411000654

Kirkpatrick, A. (2014). English in Southeast Asia: Pedagogical and policy implications. World Englishes, 33(4), 426-438. https://doi.org/10.1111/weng. 12105

Kirkpatrick, R. (Ed.). (2015). English Language Education Policy in Asia (Vol. 11). Springer. https://doi.org/10.1007/978-3-319-22464-0

Kubota, R., \& McKay, S. (2009). Globalization and language learning in rural Japan: The role of English in the local linguistic ecology. Tesol Quarterly, 593-619. https://doi.org/10.1002/j.1545-7249.2009.tb00188.x

Lang, K., \& Siniver, E. (2006). The return to English in a non-English speaking country: Russian immigrants and native Israelis in Israel. National Bureau of Economic Research. https://doi.org/10.3386/w12464

Le Ha, P. (2013). Issues surrounding English, the internationalisation of higher education and national cultural identity in Asia: A focus on Japan. Critical Studies in Education, 54(2), 160-175. https://doi.org/10.1080/17508487.2013.781047

Levinsohn, J. (2007). Globalization and the returns to speaking English in South Africa. In A. Harrison (Ed.), Globalization and poverty (pp. 629-646). University of Chicago Press. https://doi.org/10.7208/chicago/9780226318004.003.0016

Markee, N. (2000). Some thoughts on globalization: A response to Warschauer. TESOL Quarterly, 34(3), 569574. https://doi.org/10.2307/3587745

Maslach, C., Jackson, S. E., \& Leiter, M. P. (1996). The Maslach Burnout Inventory manual (3rd Ed.). Palo Alto, CA: Consulting Psychologists Press.

Maslow, A. H. (1943). A theory of human motivation. Psychological Review, 50(4), 370. 
https://doi.org/10.1037/h0054346

Matell, M. S., \& Jacoby, J. (1972). Is there an optimal number of alternatives for Likert-scale items? Effects of testing time and scale properties. Journal of Applied Psychology, 56(6), 506. https://doi.org/10.1037/h0033601

Maurer, T. J., \& Pierce, H. R. (1998). A comparison of Likert scale and traditional measures of self-efficacy. Journal of Applied Psychology, 83(2), 324. https://doi.org/10.1037/0021-9010.83.2.324

Melitz, J. (2016). English as a global language. In V. Ginsburgh \& W. Shlomo (Eds.), The Palgrave Handbook of Economics and Language (pp. 583-615). Springer. https://doi.org/10.1007/978-1-137-32505-1_21

Mesch, G. S. (2003). Language proficiency among new immigrants: the role of human capital and societal conditions: the case of immigrants from the FSU in Israel. Sociological Perspectives, 46(1), 41-58. https://doi.org/10.1525/sop.2003.46.1.41

Munshi, K., \& Rosenzweig, M. (2006). Traditional institutions meet the modern world: Caste, gender, and schooling choice in a globalizing economy. The American Economic Review, 96(4), 1225-1252. https://doi.org/10.1257/000282806779468607

Neeley, T., \& Tracy, D. (2016). Unearned Status Gain: Evidence from a Global Language Mandate. Academy of Management Journal, 59(1), 14-43. https://doi.org/10.5465/amj.2014.0535

Newton, J. (2015). The Politics of English: South Asia, Southeast Asia, and the Asia Pacific. English World-Wide, 36(3), 356. https://doi.org/10.1075/eww.36.3.04new

Nguyen, N. T. (2017). Thirty Years of English Language and English Education in Vietnam: Current reflections on English as the most important foreign language in Vietnam, and key issues for English education in the Vietnamese context. English Today, 33(1), 33-35. https://doi.org/10.1017/S0266078416000262

Nunan, D. (2003). The impact of English as a global language on educational policies and practices in the Asia Pacific region. TESOL Quarterly, 37(4), 589-613. https://doi.org/10.2307/3588214

Peltokorpi, V., \& Vaara, E. (2012). Language policies and practices in wholly owned foreign subsidiaries: A recontextualization perspective. Journal of International Business Studies, 43(9), 808-833. https://doi.org/10.1057/jibs.2012.28

Prodromou, L. (1992). What culture? Which culture? Cross-cultural factors in language learning. ELT Journal, 46(1), 39-50. https://doi.org/10.1093/elt/46.1.39

Ramanathan, V., \& Morgan, B. (2007). TESOL and policy enactments: Perspectives from practice. Tesol Quarterly, 41(3), 447-463. https://doi.org/10.1002/j.1545-7249.2007.tb00080.x

Schiffman, H. F. (1998). Linguistic culture and language policy. Psychology Press.

Smotrova, T. (2009). Globalization and English language teaching in Ukraine. Tesol Quarterly, 43(4), 727-732. https://doi.org/10.1002/j.1545-7249.2009.tb00200.x

Song, J. (2011). Globalization, children's study abroad, and transnationalism as an emerging context for language learning: A new task for language teacher education. Tesol Quarterly, 45(4), 749-758. https://doi.org/10.5054/tq.2011.268059

Stohr, T. (2015). The returns to occupational foreign language use: Evidence from Germany. Labour Economics, 32, 86-98. https://doi.org/10.1016/j.labeco.2015.01.004

Tupas, R., \& Salonga, A. (2016). Unequal Englishes in the Philippines. Journal of Sociolinguistics, 20(3), 367381. https://doi.org/10.1111/josl.12185

Vaillancourt, F. (1996). Language and socioeconomic status in Quebec: measurement, findings, determinants, and policy costs. International Journal of the Sociology of Language, 121(1), 69-92. https://doi.org/10.1515/ijsl.1996.121.69

Vandenbroucke, M. (2016). Socio-economic stratification of English in globalized landscapes: A market-oriented perspective. Journal of Sociolinguistics, 20(1), 86-108. https://doi.org/10.1111/josl.12166

Van Tubergen, F., \& Kalmijn, M. (2005). Destination-Language Proficiency in Cross-National Perspective: A Study of Immigrant Groups in Nine Western Countries 1. American Journal of Sociology, 110(5), 14121457. https://doi.org/10.1086/428931

Van Tubergen, F., \& Kalmijn, M. (2009). Language proficiency and usage among immigrants in the Netherlands: 
Incentives or opportunities? European Sociological Review, 25(2), $169-182$. https://doi.org/10.1093/esr/jen043

Warschauer, M. (2000). The changing global economy and the future of English teaching. Tesol Quarterly, 34(3), 511-535. https://doi.org/10.2307/3587741

Wei, R., \& Su, J. (2015). Surveying the English language across China. World Englishes, 34(2), $175-189$. https://doi.org/10.1111/weng.12132

Wolff, M. (2010). China's English mystery-the views of a China 'foreign expert'. English Today, $26(4), 53$. https://doi.org/10.1017/S0266078410000350

Wu, Y. A. (2001). English language teaching in China: Trends and challenges. TESOL Quarterly, $191-194$. https://doi.org/10.2307/3587867

Zein, M. S. (2017). Elementary English education in Indonesia: Policy developments, current practices, and future prospects: How has Indonesia coped with the demand for teaching English in schools? English Today, 33(1), 53-59. https://doi.org/10.1017/S0266078416000407

\section{Copyrights}

Copyright for this article is retained by the author, with first publication rights granted to the journal.

This is an open-access article distributed under the terms and conditions of the Creative Commons Attribution license (http://creativecommons.org/licenses/by/4.0/). 